\title{
Intellectual potential of pupils diagnosed with Down syndrome and intellectual disability according to their parents
}

\section{KEYWORDS}

intellectual potential, Down

syndrome, intellectual disability

\begin{abstract}
Krystyna Popowska, Intellectual potential of pupils diagnosed with Down syndrome and intellectual disability according to their parents. Culture - Society - Education no. 2(18) 2020, Poznań 2020, pp. 397-410, Adam Mickiewicz University Press. ISSN 2300-0422. DOI 10.14746/ kse.2020.18.14.2.

Research was conducted to find out about the parents' opinions on the intellectual potential of their children with Down syndrome and diagnosed intellectual disability studying in 4-8 grades of common, integration and special schools. Additionally, the factors determining the respondents' opinions were analyzed. The paper uses the author's questionnaire was placed on groups for parents of children with Down syndrome on the social network site Facebook. In addition, surveys were sent by e-mail to the primary school districts and non-governmental organizations that help children with Down syndrome. Fifty two questionnaires were collected. The results indicate that, despite intellectual disability, parents recognize the intellectual potential of their children. It can be assumed that assessments of the intellectual potential of students with Down syndrome and diagnosed intellectual disability are determined by their siblings in the intellectual norm, gender, using verbal speech, communication skills, social skills and opinions of their parents about their successes in school and progress as a result of the therapy.
\end{abstract}




\section{Foreword}

The concept of intellectual potential does not have a clear definition. The term "potential" is used in technical, social and humanistic sciences as well as in informal speech. According to the Nowa encyklopedia powszechna PWN, "potential" means "someone's resources of possibilities, abilities, means, etc. in a given field" (Kaczorowski, 2004: 742). In physics, it means "the value characterising the condition of an electric, magnetic or gravitational field in a given spot" (Szymczak, 1979: 854). Potential is also defined as a pool of resources and possibilities. In social and humanistic sciences, it is understood in the context of the possibilities of an individual and the individual's environment. According to representatives of humanistic psychology, the main goal of a human being is to "strive to increase one's potential" (Zimbardo, 1999: 27). For the purpose of this paper, potential is defined as "all intellectual and material resources, skills, abilities and capacities that may help an individual develop or achieve goals" (Krupiński, Jankowiak, 2012: 237). According to this definition, potential comprises biological and environmental resources. If properly used, such potential may be very beneficial in the development of an individual. However, if misused, it may hinder development. The intellectual resources of an individual are linked with intelligence, which may be understood as "the overall ability to learn from experience and go beyond the available information about the environment" (Zimbardo, Gerrig, 2012: 406; Gottfredson, 1997: 13). This is an ability whose evaluation is based on how it is manifested in behaviour through practical, social and cognitive skills. In these deliberations, I understand intellectual potential as the individual's ability to absorb and use their capacity to adapt to circumstances by observing abstract relationships, learning from past experiences and effectively controlling their own cognitive processes. It is conditioned by the cognitive processes taking place in brain structures. Children with Down syndrome often develop in the prenatal period central nervous system disorders, which result in intellectual disability (Pawełczyk, Pacholczyk, 2012: 207-208).

The nervous system of children with Down syndrome is affected by retardation of prenatal neurogenesis, defective pre- and postnatal synaptogenesis and cortical dysmorphogenesis. Compared to the brains of children with normal karyotype, the brain of children with Down syndrome has smaller volume and weight. The intelligence quotient of persons with Down syndrome ranges between 30 and 70 . They are mostly diagnosed with moderate or severe intellectual disability (Zasępa, 2008: 14). It is the cardinal feature of this disorder, however, it is not always present. According to research conducted by Ewa Zasępa (2003: 37) in a group of 40 
children with trisomy 21 aged between 2,8 and 16,6 years, 2,5\% of children were within the intellectual norm. Chapman i Hesketh (2000: 84-95) note the behavioural phenotype of persons with Down syndrome determined by: medical care, therapy, knowledge about Down syndrome, social awareness of what the syndrome is about and place of residence. These factors change in time depending on the socio-cultural system and individual history. The behavioural phenotype is manifested in different ways, depending on age (Zasępa, 2003: 14).

Janet Carr writes that "concerning intelligence in Down syndrome, it is enough to say that as no two children with Down syndrome are physically identical also no two children are identical in terms of intelligence. In every age group and at every stage of development, differences in the intelligence level are probably higher in the population with Down syndrome than in so-called normal population. This, of course, has implications for almost every statement concerning learning and behaviour connected with learning in children with Down syndrome" (after: Stratford, 1993: 104-105). Agnieszka Żyta (2011: 42) notes that the specificity of neurological development may affect the ability to learn. The intelligence quotient reduces with age. Cognitive functions reach their plateau at youthful age. Accordingly, the literature on the subject stresses the need for early introduction of special needs education programmes in order to improve the cognitive abilities of persons with Down syndrome (Pawełczyk, Pacholczyk, 2012: 207). Sandy Alton (1998: 167-173) identifies the following features that affect their learning:

- hypotonia,

- sensory deficits: hearing and vision,

- cognitive delay,

- difficulties with short-term auditory memory,

- difficulties with speech and language,

- shorter focus of attention,

- cognitive delay,

- difficulties with generalising and linking new knowledge with the already acquired knowledge and storing and understanding knowledge,

- learning ability based on the use of visual perception,

- ability to use and learn signs, gestures, visual prompts and written language. Joanna Kruk-Lasocka and her assistants (2017: 132) note that the current tendency in Poland is to introduce inclusive education, but it is not possible to make education fully inclusive at this stage. Instead, there are inclusion classrooms. For children with Down syndrome, learning together with pupils who develop normally stimulates their language and speech, improving their social and emotional level as well as their reading, writing and computing skills and 
general knowledge. Children with trisomy 21 reach a higher level of social functioning than other children with intellectual disability. It is believed that they have better chances to be successful in inclusive education than other children with intellectual disability (Żyta, 2011: 49). Inclusive education should be based on an individualised education plan, requirements and methods of instruction, knowledge of the weaknesses and strengths of pupils and a positive attitude of teachers, workers, pupils and teachers to inclusive education (Johnson, 2006; Hughes, 2006). Magdalena Christ (2013: 18-36) notes the need to diagnose the specific skills of children who develop normally and to implement an individualised education process in order to increase the effectiveness of teaching. Individual needs of pupils is the focal point of Howard Gardner's theory of multiple intelligences.

According to that theory, all people have all kinds of intelligence. Since every individual has different experiences, there are not two persons with identical intellectual profile and the level of intellectual development does not necessarily result in intelligent behaviour (Christ, 2015: 68). The same as Robert Sternberg (1985: 45 ), she believes that IQ tests do not give a full image of intelligence. According to the theory of multiple intelligences, intelligence is measured on the basis of observation and evaluation of a person both in everyday life situations and in situations assessed in traditional IQ tests. A correct measurement provides information on the strengths and weaknesses profile of the diagnosed individual.

According the Gardner, an individual may have multiple dominant intelligences. Depending on the number of dominant intelligences, two profiles are identified: the searchlight profile of persons with several dominant intelligences and the laser profile of persons with one or two intelligences (Zimbardo et al., 2012: 389). Since every individual has different experiences, there are not two persons with identical intellectual profile and the level of intellectual development does not necessarily result in intelligent behaviour (Christ, 2015: 68).

Jolanta Faliszewska identigies the most important assumptions of the theory for education and development of curricula:

- every individual has all types of intelligence at different stages of development;

- multiple intelligences create a profile that is unique for every individual;

- the profile is dynamic and changes as the individual develops;

- all intelligences collaborate with one another in different configurations;

- multiple intelligences may be developed through various exercises;

- proper organisation of the school and home environment stimulates the development of multiple intelligences (Faliszewska, 2009: 11-12). 
The theory of multiple intelligences is applied in education in many countries across the world, for example in Norway, Japan, Argentina, Chile (Armstrong, 2009: 203). It is also becoming popular in Poland (Christ, 2013: 33). The assumptions listed by Faliszewska take into account the individual needs and skills of a pupil. The curriculum should be tailored to the pupil's dominant intelligences so that they can fully develop their potential. Optimal conditions for development depend on the school and home environments, and on cooperation between teachers and parents.

There are few studies on the application of Gardner's theory of multiple intelligences in the development of curricula for children with special educational needs. Chahat Vasal et all (2017: 1291-1299) claim that introduction of the theory that focuses on pupils' strengths may motivate teachers to work more effectively with them. A curriculum developed jointly by teachers and therapists will increase pupils' effectiveness in practice. If attention is every day focused on the strengths of pupils with disabilities, they will become more aware of their own skills and their self-esteem will increase.

\section{Research procedure}

The purpose of the research was to find out about the opinions of parents concerning the intellectual potential of children diagnosed with Down syndrome and intellectual disability. The factors determining the opinions of respondents were also analysed. Parents' assessment of the intellectual potential of pupils diagnosed with Down syndrome and intellectual disability compared to their peers was evaluated on the basis of an original questionnaire addressed to the parents of pupils diagnosed with Down syndrome and intellectual disability attending grades 4 to 8 of primary schools. The questionnaire consisted of open-ended and closed-ended questions.

The basic research problem was: what are the parents' opinions on the intellectual potential of their children diagnosed with Down syndrome and intellectual disability and what factors influence those opinions? The following detailed questions were asked:

1. Does the fact of having an intellectually able child determine the parents' assessment of the intellectual potential of a child diagnosed with Down syndrome and intellectual disability?

2. What form of education of a child diagnosed with Down syndrome and intellectual disability condition the parents' opinion about the child's intellectual potential? 
3. In what way does the gender of a child diagnosed with Down syndrome and intellectual disability condition the parents' opinion about the child's intellectual potential?

3. Does the ability of a child diagnosed with Down syndrome and intellectual disability to use verbal language determine the parents' opinion about the child's intellectual potential? If yes, then in what way?

Pilot research was conducted in March 2019 in a group of parents of pupils diagnosed with Down syndrome and intellectual ability attending grades 4 to 8 of primary school. The analysis covered pupils attending mainstream, inclusion and special needs schools. The questionnaire was transformed into an online survey. The survey was published in Facebook groups for parents of children with Down syndrome. They were also sent by email to the managers of primary schools and non-government organisations that assist children with Down syndrome. 52 surveys were sent back.

\section{Analysis of data}

Pilot research was conducted in March 2019 in a group of parents of pupils diagnosed with Down syndrome and intellectual ability attending grades 4 to 8 of primary school. The survey was answered by fifty women and two men. Lucyna Bobkowicz-Lewartowska notes that the problem with examining the fathers of children diagnosed with Down syndrome and intellectual disability is due to the fact that they are often not at home during the day and are not willing to share their feelings with others. Mothers are more engaged in care and more often look for social support (Bobkowicz-Lewartowska, 2014: 99-100). Six of the respondents decided to send their children diagnosed with Down syndrome and intellectual disability to mainstream school, six - to inclusion school and four - to special needs school. The number of children ranges from 1 to 6 , and most families have many children. In the research group, there were 27 parents of sons diagnosed with Down syndrome and intellectual disability and 25 parents of daughters diagnosed with Down syndrome and intellectual disability. 39 children could use verbal language.

Opinions of the respondents were measured using a 5-grade scale. The other questions were based on the theories of action, which is believed to govern the man-world relationship (Strelau, 1997: 55) and on the important impact of the environment on the activity of persons with intellectual disability (Stelter, 2009: 73). Questions concerning the opinions of parents concerning their school successes of their children diagnosed with Down syndrome and intellectual disability were 
closed-ended. The opinions of the responding parents were divided into positive and negative. Positive opinions included average, high and very high grades. The responses: low and very low were considered to be negative. The chi-square test was used in the analysis of statistical significance. The strength of association was measured using the V-Cramer test.

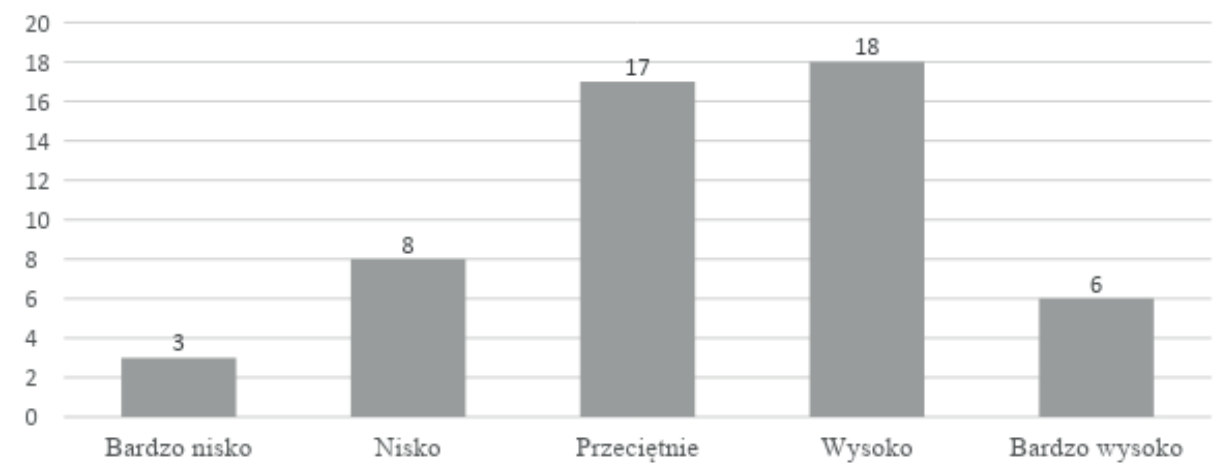

Chart 1. Parents' evaluation of the intellectual potential of pupils diagnosed with Down syndrome and intellectual disability

Source: own elaboration.

Most parents of pupils diagnosed with Down syndrome and intellectual disability evaluate the intellectual potential of their children as average or high. Eight parents evaluated the intellectual potential of their children as low. The least frequently chosen responses were: very high and very low. It may be noted that the respondents see the intellectual potential of their children.

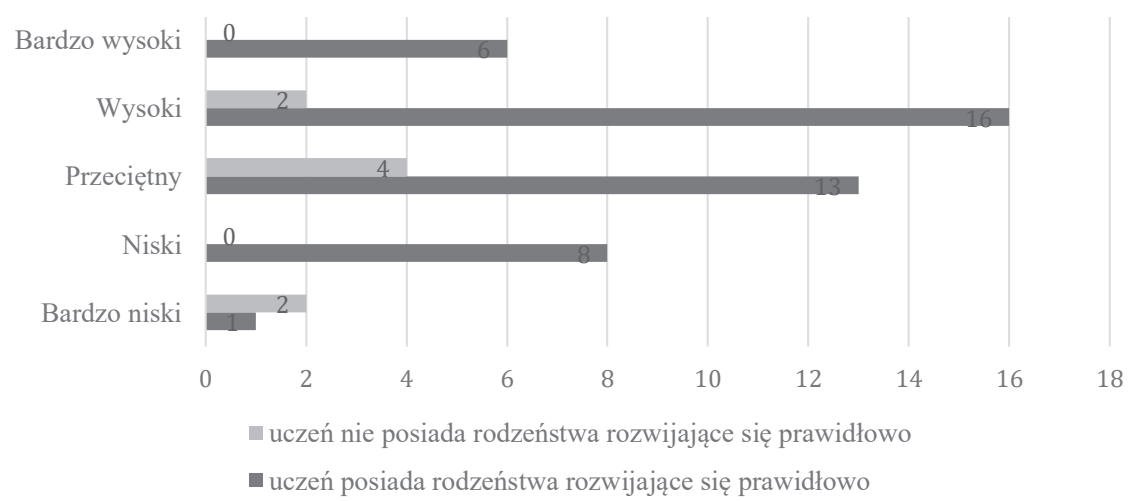

Chart 2. Relationship between opinions on the intellectual potential of a pupil diagnosed with Down syndrome and intellectual and the fact of having normally developing siblings 
Thirty-five respondents who also have normally developing children evaluated the intellectual potential of their children as positive and nine - as negative. The respondents' opinions are positive. 2 of the respondents raise more than one child who is not developing normally. Having siblings that develop normally offers opportunities for frequent training of social skills in everyday situations. The results turned out to be statistically significant $\left(\chi^{2}=\mathrm{df}=4, \mathrm{p}=0,045326\right)$. A moderate correlation $(\mathrm{V}=0,432455)$ was reported between the evaluation of the intellectual potential of pupils diagnosed with Down syndrome and intellectual disability and the fact of having normally developing siblings.

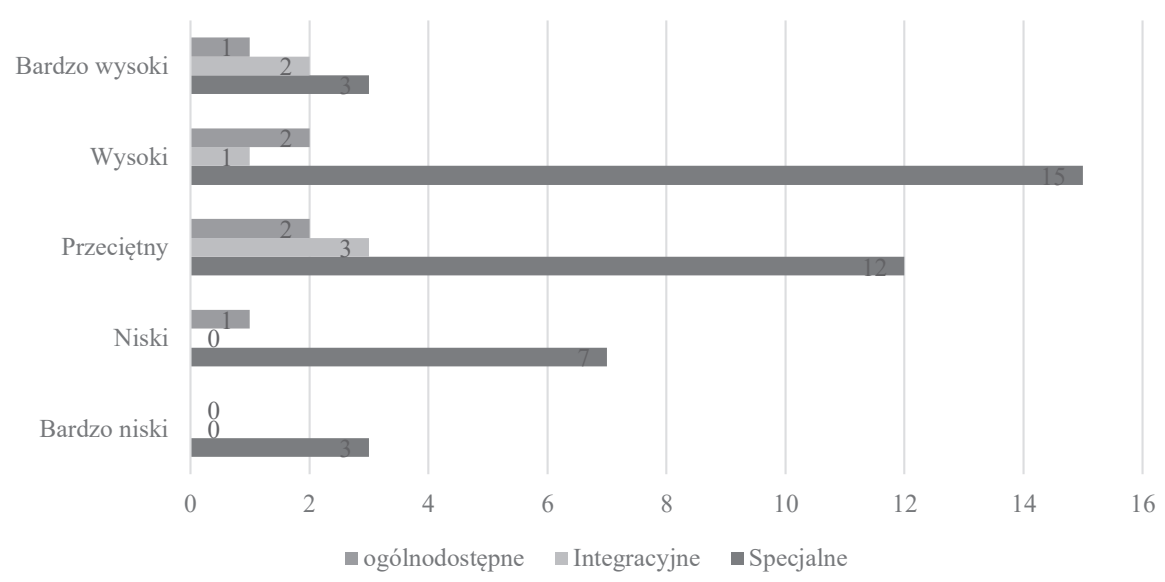

Chart 3. Relationship between opinions on the intellectual potential of a pupil diagnosed with Down syndrome and intellectual and the type of education

Source: own elaboration.

Respondents, whose children go to mainstream and inclusion schools more often evaluated the intellectual potential of their children as high or very high. All children, whose intellectual potential was evaluated as very low attend special needs schools. Everyday contacts of children diagnosed with Down syndrome and intellectual disability affects the perception of their self-dependence, social skills and their acceptance by the environment. According to the analysis, there is no statistical significance $\left(\chi^{2}=6,41468, \mathrm{df}=8, \mathrm{p}=0,600886\right)$.

Evaluation of the intellectual potential of boys and girls diagnosed with Down syndrome and intellectual disability is similar. The main differences concern the average grade. The intellectual potential of pupils diagnosed with Down syndrome and intellectual disability was most often diagnosed as average. Meanwhile, the 
intellectual potential of girls diagnosed with Down syndrome and intellectual disability was more often evaluated as low or high, the latter being the more frequent of the two opinions. Parents are more careful evaluating the intellectual potential of their sons. The distribution of values in the $\chi^{2}$ test $\left(\chi^{2}=2,45285, \mathrm{df}=4\right.$, $\mathrm{p}=0,653098$ ) shows a weak correlation between variables.

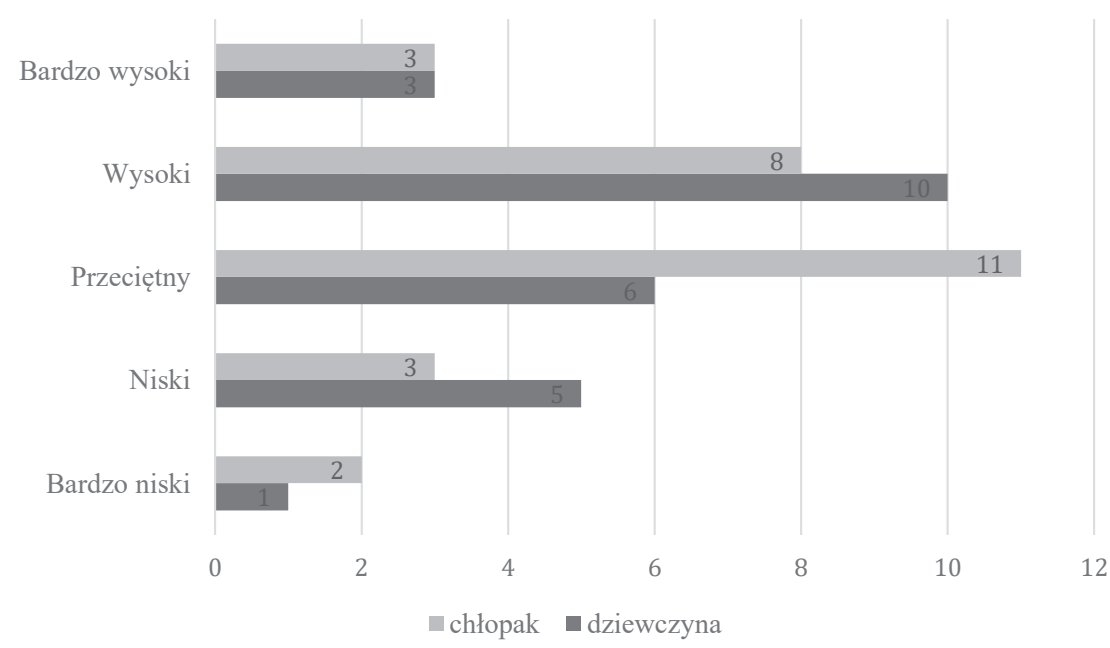

Chart 4. Relationship between the intellectual potential of a pupil diagnosed with Down syndrome and intellectual disability and gender

Source: own elaboration.

Thirteen children of the respondents do not use verbal language. The intellectual potential of eleven of those children was evaluates as average or lower. Parents of two children diagnosed with Down syndrome and intellectual disability who do not use verbal language evaluated the potential of their children as high. Very high grades were only given to children who use verbal language. Statistically, there exists a moderate correlation between the ability of a child diagnosed with Down syndrome and intellectual disability to use verbal language and the respondents' evaluation of their intellectual potential $\left(\chi^{2}=7,590414\right.$, $d f=4, p=0,107788$, $\mathrm{V}=0,3820595$ ).

Analysis of the responses shows that opinions on $n$ the intellectual potential of children diagnosed with Down syndrome and intellectual disability are moderately conditioned by: 
- The level of child's self-dependence $\left(\chi^{2}=27,71499, \mathrm{df}=16, \mathrm{p}=0,03419\right.$, $\mathrm{V}=0,3650276$ ).

- Child's progress in therapy $\left(\chi^{2}=41,61591, \mathrm{df}=16, \mathrm{p}=0,00045\right.$, $\mathrm{V}=0,4472991)$.

- Communication skills $\left(\chi^{2}=37,19650, d f=16, p=0,00197, V=0,4228822\right)$.

- Social skills $\left(\chi^{2}=23,85387, \mathrm{df}=16, \mathrm{p}=0,09274, \mathrm{~V}=0,3453540\right)$.

- School success $\left(\chi^{2}=8,130719, \mathrm{df}=4, \mathrm{p}=0,0869, \mathrm{~V}=0,39544238\right)$.

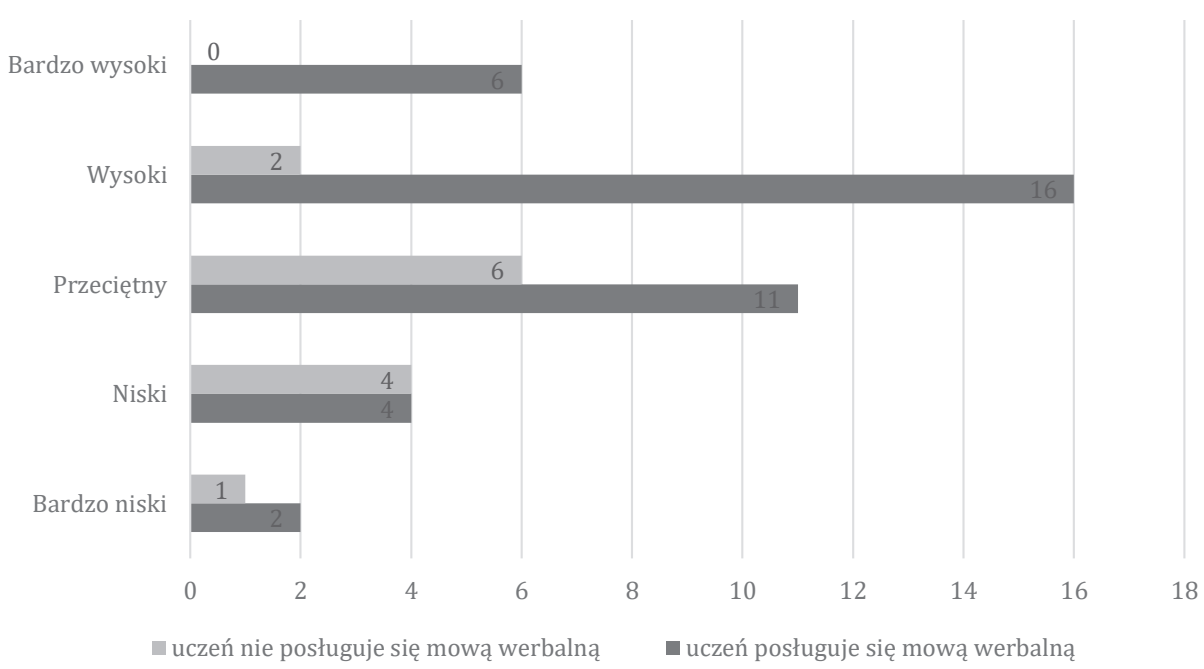

Chart 5. Relationship between the intellectual potential of a pupil diagnosed with Down syndrome and intellectual disability and their ability to use verbal language

Source: Own elaboration.

Moreover, it should be noted that the majority of opinions on therapeutic support offered by the State as well as by the non-government sector were negative, which means that it is necessary to evaluate the existing system of assistance to families of pupils diagnosed with Down syndrome and intellectual disability and to implement new solutions. In the mainstream education system implemented in Poland, school success is dependent on the cognitive processes of children, in particular their thinking. Pupils with Down syndrome have cognitive development disorders already in the pre-natal stage. Research shows that parents evaluate differently the school success of normally developing pupils and of pupils diagnosed with Down syndrome and intellectual disability. 


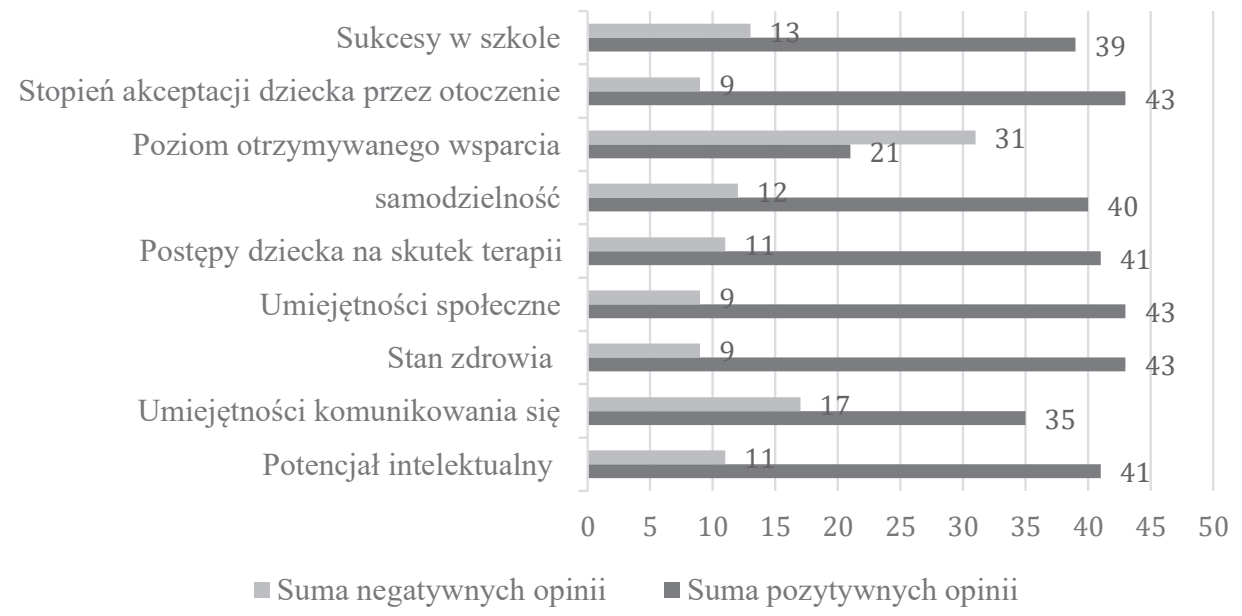

Chart 6. Breakdown of the total amounts of positive and negative opinions for each category and the most frequent responses of parents of pupils diagnosed with Down syndrome and intellectual disability

Source: own elaboration.

\section{Discussion}

The research results presented in this paper show that the opinions of parents of pupils diagnosed with Down syndrome and intellectual disability are different but mostly positive. Parents notice the intellectual potential of their children and usually evaluate it as average or high. It may be concluded that cognitive processes do not determine the opinions of parents concerning the intellectual potential of their children diagnosed with Down syndrome and intellectual disability. Moreover, a number of factors determining parents' opinions were identified, including: communication skills, the use of verbal language, social skills, progress in therapy, self-dependence, having normally developing siblings and school successes of pupils diagnosed with Down syndrome and intellectual disability. The probable reasons are observing children for many years and acquiring new skills that enable children to improve in various social situations. This, however, is a hypothesis that requires more in-depth research.

The results concerning social skills and acceptance by the environment suggest a high level of interpersonal intelligence of children diagnosed with Down syndrome and intellectual disability. Identification of strengths and individualised 
education plan for both pupils with special educational needs and normally developing pupils ensures proper teaching, upbringing and rehabilitation of a child with disability and increases chances for successful inclusion. It would be a good idea to conduct research on the types of intelligence according to Howard Gardner's theory in order to find effective ways to use the possibilities of pupils diagnosed with Down syndrome and intellectual disability. Knowledge of the potential and possibilities of pupils diagnosed with Down syndrome and intellectual disability will make it possible to develop vocational counselling for this group of people to facilitate their future participation in the open labour market.

Research has shown that the respondents are dissatisfied with the therapeutic support offered by the State and by the non-government sector. This means that it is necessary to evaluate the existing system of assistance to families of pupils diagnosed with Down syndrome and intellectual disability and to implement new solutions. It is also worth noting the opinion expressed by Magdalena Lejzerowicz (2016: 134-152) who suggests that persons with disabilities and their carers should be included in the process of designing and implementing support measures. Inclusions classrooms that provide for the individual needs of all pupils may help reduce stigmatisation of persons with disabilities. This conclusion is in line with the results of research conducted by Agnieszka Żyta and Katarzyna Ćwirynkało (2015:377-398). It is necessary to introduce changes in education and training of professionals. Interdisciplinary teamwork, communication skills and holistic approach focused on the family are essential (Taanila, 2002: 1289-1291).

\section{Bibliography}

Alton S. (1998), Differentiation not discrimination: Delivering the curriculum for children with Down's syndrome in mainstream schools, „Support for Learning”, vol. 13 (4), pp. 167-173.

Armstrong T. (2009), Multiple intelligences in the classroom, Alexandria.

Carr J. (1993), The Development of Intelligence, in: B. Stratford, Zespół Downa: przeszłość, teraźniejszosśc i przyszłość, Warszawa, pp. 104-105.

Chahat V. et al. (2017), Identifying strengths of children with special needs using multiple intelligence theory, „Indian Journal of Health and Well-being”, 8, 11, pp. 1291-1299.

Champan R.S., Hesketh L.J. (2000), Behavioral phenotype of indyviduals with Down syndrome, „Mental Reatardation and Developmental Disabilities Research Reviews", 6, pp. 84-95.

Christ M. (2013), Indywidualizacja procesu kształcenia jako wyzwanie edukacyjne XXI wieku, „Colloquium Wydziału Nauk Humanistycznych i Społecznych AMW", I, pp. 19-36.

Christ M. (2015), Indywidualizacja procesu kształcenia uczniów edukacji wczesnoszkolnej, Katowice. Cuningham C. (1992), Dzieci z zespołem Downa. Poradnik dla rodziców, Warszawa, pp. 105-106. 
Faliszewska J. (2009), Odkrywam siebie. Ja i moja szkoła. Program edukacji wczesnoszkolnej w klasach I-III szkoły podstawowej, Kielce, pp. 11-12.

Gardner H.(1993), Creating Minds, New York.

Gottfredson L. (1997), Intelligence and social policy, „Intelligence”, vol. XXIV, pp. 13-23.

Kaczorowski B. (2004), Nowa encyklopedia powszechna PWN, vol. VII.

Kazanowski Z. (2015), Społeczny wymiar współczesnej koncepcji niepełnosprawności intelektualnej, „Annales Universitatis Mariae Curie-Sklodowska Polonia - Lublin”, vol. XXVIII, 1, pp. 33-43.

Kruk-Lasocka J. et al. (2017), Dziecko z zespołem Downa w szkole ogólnodostępnej?, „Lubelski Rocznik Pedagogiczny", vol. XXVI, 2, pp. 131-148.

Krupiński R., Jankowiak A. (eds.) (2012), Słownik psychologiczny. Leksykon ludzkich zachowań, Konin.

Lejzerowicz M. (2016), Włączanie i integracja a stygmatyzacja osób z niepetnosprawnością w polskiej edukacji, „Forum Oświatowe”, 28, 1 (55), pp. 134-157, https://forumoswiatowe.pl/index.php/ czasopismo/article/view/426.

Łoś A., Wrońska J. (2014), Wspomaganie rozwoju dziecka z zespołem Downa, in: J. Skibińska, Wspomaganie rozwoju dziecka, Kraków.

Midro A. (2008), Zespół Downa. Przyczyny powstawania, diagnoza i elementy poradnictwa genetycznego, in: Wspomaganie rozwoju dzieci z zespołem Downa - teoria i praktyka, ed. B. Kaczmarek, Kraków.

Minczakiewicz E.M. (2010), Księga pytań i odpowiedzi. Zespół Downa, Gdańsk.

Pawełczyk M., Pacholczyk M. (2012), Zespół Downa a niepetnosprawność intelektualna, in: K. Bobińska et al., Niepetnosprawność intelektualna - etiopatogeneza, epidemiologia, diagnoza, terapia, Wrocław, pp. 206-208.

Pochon R., Declercq C. (2013), Emotion recognition by children with Down syndrome: A longitudinal $s t u d y$, „Journal of Intellectual \& Developmental Disability”, 38, 4, pp. 332-343.

Sadowska L. i in. (2005), Syntetyczna ocena zmian strukturalnych mózgu w badaniu magnetycznym rezonansem jądrowym (MRI) u leczonych osób z zespołem Downa (ZD), „Przegląd Medyczny Uniwersytetu Rzeszowskiego", pp. 252-261.

Schalock R.L. et al. (2010), Intellectual Disability. Definition, Classification, and Systems of Supports, Washington.

Stelter Ż. (2009), Dorastanie osób z niepetnosprawnościa intelektualną, Warszawa.

Sternberg R.J. (1985), Beyond IQ: A triarchic theory of human intelligence, New York.

Strelau J. (1997), Inteligencja człowieka, Warszawa.

Šustrová M., Šariková V. (1997), Down’s Syndrome - The Impact of Increased Expression of Genes of the 21st Chromosome on the Functions of Immunity and Nervous Systems, „Bratisl Lek Listy”, p. 22.

Szymczak M. (ed.) (1979), Stownik języka polskiego, Warszawa.

Taanila A. (2002), Well-presented first information supports parents' ability to cope with a chronically ill or disabled child, „Acta Paediatrica”, vol. 91, no. 12, pp. 1289-1291.

Winczura B. (2014), Mowa i język dzieci z zespołem Downa - czynniki zakłócajace, in: Dzieci o specjalnych potrzebach komunikacyjnych. Diagnoza - edukacja - terapia, ed. B. Winczura, Kraków, p. 20.

Wołosiuk B.A. (2016), Rozwijanie komunikacji językowej u osób z zespołem Downa, „Społeczeństwo i Rodzina: stalowowolskie studia Katolickiego Uniwersytetu Lubelskiego", 3, pp. 58-70.

Zasępa E. (2003), Rozwój intelektualny dzieci z zespołem Downa, Warszawa.

Zasępa E. (2008a), Przebieg procesów pamięci u osób z zespołem Downa, in: Wspomaganie rozwoju dzieci z zespołem Downa - teoria i praktyka, ed. B. Kaczmarek, Kraków, pp. 155-160. 
Zasępa E. (2008b), Psychospołeczne funkcjonowanie osób z zespołem Downa, Kraków.

Zasępa E. (2012), Psychospołeczne funkcjonowanie osób z zespołem Downa, Kraków.

Zimbardo P.G. (1999), Psychologia i życie, Warszawa.

Zimbardo P.G., Gerrig R.J. (2012), Psychologia i życie, Warszawa.

Zimbardo P.G., Johnson R.L., McCann V. (2010), Psychologia. Kluczowe koncepcje, Warszawa.

Żyta A. (2011), Życie z zespołem Downa. Narracje biograficzne rodziców, rodzeństwa i dorosłych osób z zespołem Downa, Kraków.

Żyta A., Ćwirynkało K. (2015), Wspieranie rodzin dzieci z niepełnosprawnościa - perspektywa zmiany, „Wychowanie w Rodzinie”, vol. XI, pp. 377-398. 